\title{
THE 'ON AND OFF' OF FAITH IN HYPERMODERNITY: RELIGION AND THE NEW INTERFACES OF THE SACRED IN THE MEDIA ERA
}

\author{
O ON E O OFF DA FÉ NA HIPERMODERNIDADE: A RELIGIÃO E AS \\ NOVAS INTERFACES DO SAGRADO NA ERA MIDIÁTICA
}

- JEFFERSON R. DE OLIVEIRA ${ }^{1}$

1 Ph.D. in Human geography with emphasis on Cultural Geography and Geography of Religion at State University of Rio de Janeiro - UERJ. Rio de Janeiro, Brazil. Pós-doutor em geografia com ênfase em Geografia Cultural e Geografia da Religião pela Universidade do Estado do Rio de Janeiro - UERJ. E-mail: jeffersongeouerj@yahoo.com.br

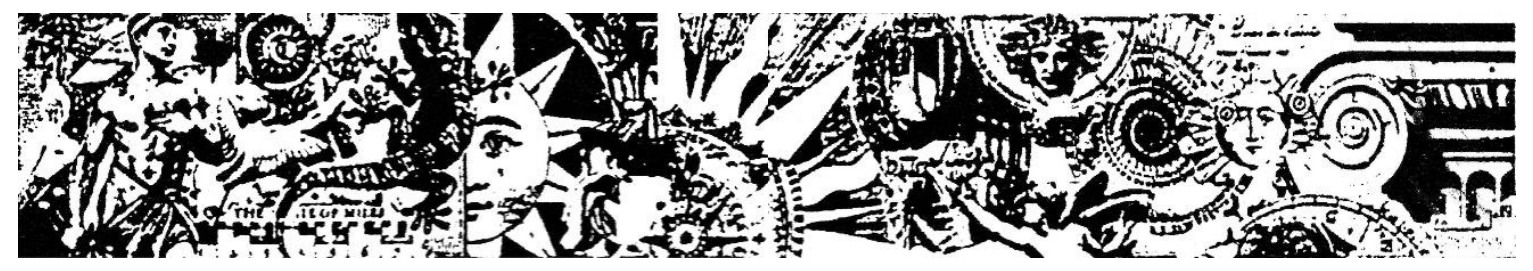

Abstract: Based on the post-1989 Cultural Geography studies and the Geographic studies of Religion, the present essay aimed to explore the relationship between religion and media in the age of 2.0, the age of social networks and the diffusion of media. In order to achieve this goal, we tried to understand how these new social relations occur through hypermodernity, which is characterized by the culture of excess, the intensification of values and a greater diversification of production aimed at consumption. We have also discussed how the process of development and propagation of the media and the cyberspace create new strategies for diffusion of faith. Through political, economic and local dimensions, we were able to understand the new connections between the sacred, the faith and the new dynamics of hypermodern society. The Roman Catholic Church in Brazil and the new spatial and territorial transformations through cyberspace and media are the empirical examples of the present research.

Keywords: Cultural Geography; Geography of Religion; hypermodernity; space; religion; media. 


\section{O ON E O OFF DA FÉ NA HIPERMODERNIDADE: A RELIGIÃO E AS NOVAS INTERFACES DO SAGRADO NA ERA MIDIÁTICA}

Resumo: Com base nos estudos da Geografia Cultural pós-1989 e nos estudos Geográficos da Religião, o presente artigo tem por objetivo, explorar as relações entre religião e mídia na era 2.0, a era das redes sociais e de difusão midiática. Para atingir os objetivos propostos, procuramos entender como essas novas relações sociais ocorrem através da hipermodernidade, caracterizada pela cultura do excesso, pela exacerbação de valores e pela ampla diversificação da produção voltada ao consumo. Também iremos discutir como o processo de desenvolvimento e propagação da mídia e do ciberespaço criar estratégias para a difusão da fé. Por meio das dimensões política, econômica e do lugar, poderemos entender as novas conexões entre o sagrado, a fé e as novas dinâmicas da sociedade hipermoderna. A Igreja Católica Romana no Brasil e as novas transformações espaciais e territoriais através do ciberespaço e da mídia, serão os exemplos empíricos do presente trabalho.

Palavras-chave: Geografia Cultural; Geografia da religião; hipermodernidade; espaço; religião; meios de comunicação.

\section{EL ON Y OFF DE LA FE EN LA HIPERMODERNIDAD: LA RELIGIÓN Y LAS NUEVAS INTERFACES DE LOS SAGRADOS EN LA ERA MEDIATICA}

Resumen: Basándose en estudios posteriores a 1989 de Geografía Cultural y Estudios Geográficos de la Religión, este artículo tiene como objetivo explorar la relación entre religión y medios en la era 2.0 , la era de las redes sociales y de la difusión de los medios. Para lograr los objetivos propuestos, buscamos comprender cómo se producen estas nuevas relaciones sociales a través de la hipermodernidad, caracterizada por la cultura del exceso, la exacerbación de los valores y la amplia diversificación de la producción dirigida al consumo. También discutiremos cómo el proceso de desarrollo y difusión de los medios y el ciberespacio crean estrategias para la difusión de la fe. A través de las dimensiones política, económica y del lugar, podemos entender las nuevas conexiones entre lo sagrado, la fe y las nuevas dinámicas de la sociedad hipermoderna. La Iglesia Católica Romana en Brasil y las nuevas transformaciones espaciales y territoriales a través del ciberespacio y los medios serán los ejemplos empíricos de este trabajo.

Palabras clave: Geografía cultural; Geografía de la religión; hipermodernidad; espacio; religión; medios de comunicación.

\section{Introduction}

When we think of geography as a science and its different domains and approaches in the geographic field, we are surprised by some research fields, usually more common to the domain of other areas of knowledge, such as the social and human sciences. Despite the surprise of many, the studies of Geography of Religion in Brazil have been developed since the 1980s, derived from the studies of Renewed Cultural Geography or Cultural Geography post-1980.

The study of culture in Geography is not only analyzed in the sphere of materiality, of something concrete but also in the immateriality field, in the study of faith, music smells and tastes. The Geography happens to be everywhere, and its studies begin to have an amplification in its 
diffusion through different spatiality. The studies of Lily Kong (1990), Dennis Cosgrove (1998), Paul Claval (1999(a), 1999(b), 2012), William Norton (2000), Roberto Lobato Corrêa and Zeny Rosendahl (2003, 2008), Maria Geralda de Almeida and Alexsandro Ratts (2003), Paulo Cesar da Costa Gomes (2008), among other authors, ratify these new actions in the field of Geography.

Religion is a valuable field of analysis for Geography, once through faith: a) cities were and are built; b) urban and social transformations are implemented; c) wars and conflicts are fought; d) duels and media battles arise in different media and in cyberspace; e) the economy are changed by a new dynamism and; f) the market of symbolic goods gain a new economic force of production and sales from the spectacularization of the faith. We present here some elements that are of interest to the geographer, as we will see throughout this essay.

In this way, the geography of religion focuses on the relations between space and the sacred (ROSENDAHL, 2008). It is in the interest of the geographer how religion develops, spreads and impacts people's lives, and is rooted in geographic factors (PARK, 2004). Geographer Chris Park (1994, p.1), in his book Sacred Worlds, informs us that at first, geography and religion seem to be companions in a curious sense, but nevertheless, "even a brief reflection reveals an infinity of ways in which the two interact - religion affects people and their behavior in many different ways (...)". According to the author, "geographers have traditionally been concerned with spatial patterns, distributions and manifestations of people and the environment".

In his studies the American geographer Roger Stump (2008, p.7) points out that religion "(...) is interpreted throughout this volume as a cultural system, an integrated complex of meanings, symbols, and behaviors articulated by a community of adherents". According to Stump, as other elements of culture, religion "(...) encompasses a set of normative conceptions or "givens" that inform the ways in which people understand, act within, and influence the world that they inhabit". As regards the interest of geography in the study of religion, the author reveals that it derives from a number of factors "(...) as an integrative discipline concerned with the interactions among diverse phenomena in particular places and across space, geography provides a useful conceptual context for examining religion as an integrative element of culture" (STUMP, 2008, p.16-17).

Ratifying Stump's (2008) emphasis on religion as a cultural system, geographer David Sopher (1967, p.1) brings us that cultural geography "(..) is concerned with man, not as an individual, but as a sharer and bearer of culture. Its particular concern is with two kinds of relationships: the interaction between culture and its complex earth environment, and the spatial interaction between different cultures". From this information, the author reveals that the geography 
of religion "(...) investigates these relationships, concentrating its attention on the religious component in culture".

The connection between Geography and religion occurs through a spatial dynamic in time and space. Geography in the study of people and their actions on the Earth and Religion as a cultural phenomenon occurs in this space of human interrelations. That means that Geography and religion are intrinsically interconnected (ROSENDAHL, 2002). Based on this, we try to perform a geographic analysis of the relations between economy, politics, and space, based on faith and market in a period usually referred to as hypermodernity (LIPOVETSKY \& SERROY, 2011).

Based on our results, the present essay aims to highlight some points on the relations between religion and the media. We also try to understand how the new social relations through hypermodernity enable the emergence of new practices and spatial experiences in a hyperconnected world. This essay also discusses how the process of development and propagation of the media and the cyberspace create new strategies of diffusion of the faith. Through the political, economic and local dimensions (ROSENDAHL, 2003; OLIVEIRA, 2017), we can understand how the new relations between the sacred, the faith and the economic, political and social dynamics of hypermodern society occur. Therefore, the Roman Catholic Church in Brazil is taken as an example in the present article.

In order to achieve the proposed goals, this essay is divided into three parts: a) Hypermodernity and world culture; b) Faith, space and time in the 21st Century: the power of the media and new religious practices; c) Brazilian Catholicism and the mediatization of faith as a strategy of evangelization.

\section{Hypermodernity and world culture}

Created from the studies of the French philosopher Gilles Lipovetsky, a professor at the University of Grenoble (France), the concept of hypermodernity has been used in several sciences and in Geography, enabling a new field of analysis in relation with the new process of capitalist production. The main arguments of this concept are the intensification of values, the cultures of excess and an overwhelming cascade of products that result in consumption (LIPOVETSKY \& SERROY, 2011).

Hypermodernity is also characterized by the practice of individualism, the search for the self, the value of aesthetics, exponential marketisation, hypershows and the hyperevents, resulting in a high point of capitalism itself, aesthetic capitalism (LIPOVETSKY \& SERROY, 2015). The 
Polish sociologist Zygmunt Bauman $(2007,2008)$, through his studies on what he calls liquid modernity and liquid culture, consumer culture, mass consumption and individualized society, points that the contemporary world is marked by a liquid society whose ties and social positions are fluid and uncertain, leading to the creation and search of new practices and social experiences.

The advance of this current social chain can also be noticed in the relations that are increasingly embraced by the processes connected to the advance of the communication networks, as pointed by Castells (1999), and mainly interconnected by cyberspace and cyberculture. The philosopher, sociologist and the Information Science and Communication researcher Pierre Lévy $(1996,1999)$ discusses these studies.

Besides the term hyper, linked to the exacerbation of values created in the postmodernity and raised exponentially to excess consumption and to individualism, hypermodernity also points how fast and intense are the activities of the collective, which leads individuals to feel that time goes by fast. Thus, hypermodernity is a better term to define this speed of time that we experience nowadays.

However, it is known that time does not accelerate, since time is not something substantial, visible, but it is nonetheless felt as so, as pointed by Bauman $(2003,2008)$. We live in an era in which time is accelerated and acutely compressed, resulting in a social acceleration and in a redetermination of time, as pointed in the studies of the German sociologist and philosopher Hartmut Rosa (2010).

In a liberal society, characterized by movement, fluidity and flexibility, temporality must be interpreted through geographical spatiality. These new actions are confirmed by the fact that, with the new demands and social transformations of 21 st century capitalist society, modernity needs to adapt to the new hypermodern rhythm in order to not disappear (LIPOVETSKY \& CHARLES, 2004). The ideas presented here share the thoughts of the authors, since "society in which time is increasingly lived as a major concern, the society in which a growing temporal pressure is exerted and generalized" (LIPOVETSKY \& CHARLES, 2004, p. 75), make possible the emergence of new demands and social transformations.

Hypermodern society has as its main characteristic, besides the high degree of consumption, a new cultural front that ends up favoring the breakdown of a heterogeneous culture, of values, in order to search for a homogenization, generated mainly through the media, especially the cyberspace. According to Gilles Lipovetsky (2012), this action would be linked to what he defines as the world culture. 
[...] the concept applies to the information and communication technologies revolution, the formation of vast supranational media networks and the expansion of the cultural industry, which are introducing an ever-increasing share of the same goods into a globalized market (LIPOVETSKY, 2012, p.2).

Still, according to the author, "world culture also designates a context in which cultural operations play an increasingly decisive role in the business world through design, aesthetics, models of all kinds". It is possible to emphasize that the pattern of the cultural economy is that of the creative enterprises. By reshaping the material universe of production and commerce, culture is no longer just a sublime superstructure of signs. Today, in society, 'the logos, objects, fashion, tourism, habitat, advertising - everything tends to assume a cultural, aesthetic and semiotic tone' (LIPOVETSKY, 2012, p.2).

When we think about design and aesthetics, we refer to what Gilles Lipovetsky and Jean Serroy (2015) point out as an aestheticization of the world, inserted in the context of artist capitalism. In this sense, capitalism, once centered on a material production, as in the Fordist era, now gains a new concern, in relation with the immaterial, now supported in the imaginary, the dreams and the sensibility of people. In this way, art and market blend into contemporary experience of aesthetic value as never before.

The spatial dimension of culture gains an opportune perspective of analysis that, from the aesthetics and the collective imaginary, corresponds to the new and different social dynamics in the social patterns constructed in the paradigm of the hypermodern era. Supported by this new context, "style, beauty, the mobilization of tastes and sensibilities are increasingly imposed as strategic imperatives of brands: it is an aesthetic mode of production that defines hyperconsumption capitalism" (LIPOVETSKY \& SERROY, 2015, p.13).

Still according to Lipovetsky and Serroy (2015), the artistic capitalism or the creative transaesthetics, both inserted in the fourth era of the aestheticization of the world, are marked in the construction of the real as image, interconnecting in this process an aesthetic-emotional dimension that has become one of the main points in the competition between brands. These actions still shape artistic capitalism due to the increasing weight of what we define as markets of sensitivity and design process. The consumerist universe is intimately integrated by a systematic work of styling goods and marketplaces.

The geographer Allan Scott (2001) is in accordance with the analysis of Gilles Lipovetsky and Jean Serroy (2015) on the process of linking and relations between capitalism and culture. For the author, there is a convergence between the economic and cultural area, especially when the culture itself is increasingly characterized by commodified goods and services. 
As well as Allen Scott (2001), Gilles Lipovetsky and Jean Serroy (2015) also agree that the transaesthetic era of capitalism would be linked to the process of essential remodeling by the logic of commodification and extreme individualities. Thus, in times of aestheticization of consumer markets, artist capitalism multiplies the styles, trends, shows, and places of art. The other eras of the aesthetics of the world, categorized by the authors, would be the ritual arterialization, the aristocratic aestheticization and the modern aestheticization of the world.

There is a continuous launch of new fashions in all sectors of production providing a scale of the dream, the emotions, and the imaginary. "It is a universe of overabundance or aesthetic inflation that shapes itself before our eyes: a transaesthetic world, a kind of hyper art, in which art sneaks into industries, in every interstice of commerce and common life" (LIPOVETSKY \& SERROY, 2015).

Aesthetics, art, and design are increasingly assuming new forms in clothing, fashion, music, major events, concert, cinema, theater, architecture and symbolic forms with spatiality or not, in large urban centers of production and reproduction. This new reality of capitalist production contemplates the different market niches, such as the tastes and spheres of different social groups. It also favors cultural and artistic diversity, slowing down new dynamics in the relationships linked to the world such as cinema and music, advertising, cathedrals of consumption - shopping malls, spectacle and entertainment, hyper-shows, kitsch world, internet, cultural consumption, among others.

Religion, in this paper specifically the Roman Catholic Church, appropriates these new relations existing between artist and aesthetic capitalism for the creation of new models of production and diffusion of the faith through cyberspace, media and new symbolic religious goods produced. As our field of analysis belongs to the geographical studies of religion, from the dimension of the sacred, we are going to analyze the new relations between religion and media in the hypermodern conjuncture, in order to discuss the concepts of time, hypermodernity, media, cyberspace and new religious practices. In this aspect, the concept of time used in the present essay is a category of geographic analysis (ADAM, 2004; CORREA , 2011) and will be highlighted as part of the studies of the Geography of Religion. 
Faith, space and time in the 21st Century: the power of the media and new religious practices

Religion adapts itself to social practices. The conservative churches and the consequent loss of believers is proof that the powerful domain of religious communication must be up to date, in order to maintain the power of evangelizing management in the world. Social media and smartphone applications such as Facebook, Snapchat, YouTube, Twitter, Tumblr, Google+, Instagram, Flick, WhatsApp, among others, as well as traditional mass media as television or radio, represent instruments that allow churches to have power and control over believers.

The diffusion of faith through media in its different spheres and usage scales allows the devotee to approach the divine. Also, without immediate access to the sacred, such as going to church, chapel, or other sacred places, the devotee can practice his/her faith through television, radio, internet or even through religious applications for smartphones (OLIVEIRA, 2017).

It represents a behavior of change in the traditional environment of the church. Till then the ritual with the divine could only take place within the churches. Now, in the current postmodernity or hypermodernity, this change occurs in the rite of diffusion through contact. The devotional practice of diffusion through contact also takes place outside the church, with the appropriation of media. We can still add the condition of society for the pursuit of its self, the individuality of practice that engages the devotee to participate in the mass; to pray the rosary; to read the Bible and the gospel of the day; to participate in concerts, lectures, and countless other religious rituals without leaving home. The television, the internet or the smartphones enable religious experience in time and space.

The relations between space and religious time is embedded even in the types of pilgrimages (OLIVEIRA, 2011, 2015) and at the same time that it brings the new elements, it also shows the strategy of the church in presenting to society its traditional search, remaining conservative in the process (CARRANZA \& MARIZ, 2009). In this sense, one must point that, although there are new fronts of evangelization, the Catholic devotees continue to participate in these practices within the church.

The relation of people with divinity differs from religion to religion. Subjectivity, in the construction of religious identity, takes part in this dialogue. Why are religions different? People ask themselves and the answer is "because individual experiences are different. When they gather around under a common denominator, a religion is formed" (SKORKA \& BERGOGLIO, 2013, p. 27). 
The spread of the online faith and the different kinds of devotional expansion in message flow in the media allow the church to reach countless devotees. It represents a flow of information from the religious message through different means of different uses of information technology. The Roman Catholic Apostolic Church itself makes use of the new technologies and media to communicate with its devotees and spread the word of God, through its different fronts of diffusion of the faith, as the communities of life and alliance linked to the Catholic Charismatic Renewal (CCR) movement. It comes to a strategy in the propagation of its ideas, having achieved success through media such as Facebook pages, Twitter accounts, Instagram and Flick profiles, YouTube channels, among others.

We consider that religious individuals in hypermodernity have not only their traditional characteristics and practices of living and feeling the sacred, as highlighted by the author Greco (2009) and Rosendahl (2012) in their studies, but also present new practices of experiencing faith through media and cyberspace, that is, a virtual, imaginary and symbolic religious practice. "The religious individual is the one who has been touched by the sacred power. He/She can pray, offer sacrifices and perform religiously motivated acts, once he/she has been struck by the manifestation of the Sacred (...)". The Sacred "transforms his/her being and his/her existence, making of him/her an interlocutor and requesting his/her response. It is constituted as the subject of an experience, while it is the 'object' of divine action" (GRECO, 2009, p.87-88).

From this dynamic, the religious individual participates in masses and events that are transmitted live through networks of Catholic television, internet, and applications on smartphones. Religious time, practice and experience between the individual and the sacred may also occur through virtual chapels, virtual candles, and applications on the smartphone, such as virtual Bible, virtual confessionals, religious programs on television, among others. The thoughts of Bauman (2008) and the ideas of Lipovetsky (2004) are in dialogue with the ones discussed in the present essay. Society may be inserted in hypermodernity through the search of the self and individualism, but it may also be embedded in the liquid modernity, once the loss of values and the need to expose itself gain prominence in society.

Bauman reveals the relationship between liquid culture and a society of dual values, which is constructed when what was previously private in the self of individualism becomes collective in the virtual environment as the exhibition front. Bauman points out that 'teenagers equipped with portable electronic confessionals are only apprentices trained in the art of living in a confessional society,' that is, 'a notorious society for eliminating the frontier that once separated the private and 
the public, for transforming the act of publicly exposing the private into a virtue and public duty (...)' (2008, p.9).

Pierre Lévy (1999) definition of cyberspace and cyberculture is of extreme relevance, mainly because it looks for a comprehension of the existing relationships between a physical and concrete geographic space and a virtual geographic space, that is, a new connected world of information networks, assumed by the internet, for example.

This perspective is related to the Dimension of the Politics of Faith (ROSENDAHL, 2003; OLIVEIRA, 2017), in which we can highlight the diffusion and comprehension of the faith through the internet and the information technologies; the cyberculture; the cyber-theology; virtual religion; social media / social networks; smartphones, tablets and others. The interesting point in this perspective is the fact that such plural social relations can be brought to the geographic studies, once they are in wide expansion into a parallel universe, which is at the same time and collective due to media and social networks. Therefore, it can verify that a strong strategy has been adopted by the church. Nearly 3,773 billion people around the world (WEARESOCIAL, 2017) use these networks of information.

According to the religion scientist and communicologist Jorge Miklos (2012), religions started to use the media with the sole purpose of evangelization. Nevertheless, one can observe a web of interrelations and the construction of a consumer market in a high expansion. According to Miklos (2012, p.20), media and religion are interconnected, having "a relationship of interdependence, they form a complex conglomerate - one and diverse", that is, a channel, "a path of diffusion of symbolic goods, specifically of the religious emblems that guide the worldview proposed by the religion that uses these electronic media" (MIKLOS, 2012, p. 29).

Concerning the Roman Catholic Church in Brazil, the greatest challenge would be to keep its hegemony ahead of other religious doctrines. Due to social and cultural changes in society taken place since the end of the 20th Century and the beginning of the 21st Century, an increase in the diffusion of electronic media has reached a new range of Christian consumer masses (MIKLOS, 2012).

In the next topic, it will be discussed how these new relations occur among the Roman Catholic Church, the media and the conflictive coexistence in the face of the expansion of other religious doctrines such as Pentecostals and Neo-Pentecostals. The activities of these churches in Brazil are taken as the object of analysis. 
This action and strategy become relevant to the geographic study and allow a direct dialogue with the ideas of Peter Berger in his article "The desecularization of the world: a global vision", published in 2000. In the context of post-1960s, Berger (1985) believed that the laity of society would continue to endure for a long period. In addition, even a loss of faith could occur. However, despite visualizing a cultural change in the post-1970s world, one can notice a restoration of faith. People continue to seek religion, to establish contact with the sacred, with something that transcends their daily life, that is, the extra-quotidian.

The affirmation of a religious aggravation highlighted by Berger (2000) through the process of secularization of society did not come to fully occur as he and other social scientists thought. According to Berger (2000), "the idea is simple: modernization necessarily leads to a decline of religion, both in society and in the mentality of people. In addition, it is precisely this central idea that turned out to be wrong". The author still points out that "modernization has had some secularizing effects in some places more than in others. However, it also provoked the emergence of powerful counter-secularization movements" (BERGER, 2000, p.10).

With the resurgence of faith, notably in the late 1960s, a decade of numerous cultural and social manifestations, the Catholic religion has also followed the changes. It launches new ecclesial movements, new dynamics in the practice and religious life of the devotee. The highlight of this change is the movement of the ecclesial communities linked to the Catholic Charismatic Renewal movement (CCR), which began in 1967, after the Second Vatican Council, which reorganized the foundations of the Catholic Church in face of the questions that the society of the time had.

One characteristic that arises from the genesis of the Catholic Charismatic Renewal in the United States in 1967 and its diffusion throughout the world from that date onwards were the new communities that allowed religious individuals to have new religious practices and experiences (Greco, 2009). These communities emerged with the initial aim of spreading the movement through a diffusion by contact, from prayer meetings, camping, formations, prayer groups, among other actions that exist to the present day.

These transformations were of extreme importance for these new social conjunctures in the 21st Century. Looking for a new spatiality through hypermodernity is an opportunity for Church to expand its territories to the virtual world and the media, as well as to conquer and increase its production of symbolic religious goods. 


\section{Brazilian Catholicism and the mediatization of faith as a strategy of evangelization}

When thinking about the current religious framework in Brazil, we can highlight the effervescence of a religious pluralism. The advances of society in the 21 st Century allowed people to discover new forms of proximity to the sacred through different religious practices and actions, from the search of the sacred place to the experience from cyberspace and the media (OLIVEIRA, 2014). These changes in the hypermodern society have also allowed the proliferation of diverse doctrines, religious sects and even pseudo-religions (ELIADE, 1962) that seek, from this new conjuncture, to create new religious territories to exercise their religious territoriality, resulting in the religious diversity in Brazil.

The Catholic religion is still considered the main religion in Brazil, counting nearly $64.6 \%$ Brazilians, according to data from the Brazilian Institute of Geography and Statistics (IBGE, 2010); although in 2000 , the number of Catholics represented $73.6 \%$ of the Brazilian population.

The sociologist Flavio Pierucci presented the panorama of religions in Brazil in an interview 2 held by TV PUC at the television program Teodiversidade, in São Paulo. According to the sociologist, in a country with a certain dominant religion, as in the case of the Catholic religion in Brazil, it is very common that this majoritarian religion presents a decrease of the faithful because of the loss of believers to other religious doctrines.

Observing these changes, it becomes necessary for the majoritarian religion to create strategies of diffusion and maintenance of its territories both in physical scale and in the scale of cyberspace and media (OLIVEIRA \& ROSENDAHL, 2014).

When we think of religious territory and religious territoriality of the Catholic Church, we highlight the work of the geographer Zeny Rosendahl (2012) called "First the obligation, then the devotion: Space strategies of the Catholic Church in Brazil from 1500 to 2005". In this book, the geographer explores the different spatial strategies of maintenance and diffusion of the Catholic faith in Brazil in different historical periods.

In order to manage its territories, the Catholic Church created, from a religious territoriality, actions for better control. In relation to territoriality, one must point out that it is an action carried out individually or in a group, trying to obtain influence or control over people, phenomena, and relations, thus enabling control over a given area (SACK, 1986). According to Rosendahl (2002, 2003,2012 ), interpreting religious phenomena in such perspective is of extreme relevance, in order

\footnotetext{
${ }^{2}$ Link to the interview: https://www.youtube.com/watch?v=9HbncepXhkQ.
} 
to understand the geographic strategy of controlling people and things in territories where religion is structured as an institution.

In this way, territoriality in a religious context and from a geographical perspective would be a set of practices that a particular institution, as well as a religious or a laic social group, develop with the objective of controlling a given religious territory. In this territory, the sacred and its powerful effect convey an identity of faith in a sense of mutual ownership (ROSENDAHL, 2001). If we bring the interpretation of religious territoriality to the approach of post-1980s Cultural Geography, we may find a set of practices developed by religious institutions or groups, in order to maintain control over people or objects in a religious territory, legitimizing a certain faith (ROSENDAHL, 2005, 2008).

Throughout the work of Rosendahl (2012), one can comprehend the actions taken by the Catholic Church from 1500 to 2005, which means 505 years of studies on the management and creations of religious territories, controlled from a religious territoriality. Although the Catholic Church seems to have ensured its territories through the years, considering that the Catholic institution has been present for more than two thousand years, new strategies to control their spatial organization should be created to allow the continuity of their power relations in its territories.

In Rosendahl's studies (2012), the parish as a religious territory has a strategic role within the Catholic Church, since it represents for religious individual a close religious territory, where the actions of the Diocese and the Vatican reach the devotee, establishing a symbolic place, a link between him/her and the deity. In this case, we observe a strong religious identity in place. The parish is considered as a major religious territory of the life of local communities. As a territory, it becomes recognized since it takes control of the daily liturgy, thus being on the scale of human coexistence.

The Catholic Church, in all its hierarchical construction, maintains until today its religious territories from actions and developed practices, in the sense of controlling people and objects, legitimizing and maintaining their existence through a religious territoriality. The territorial hierarchy of the Catholic Church is built from networks, which is primarily constituted from the Vatican, where the Pope commands all territorial units, archbishops command the archdioceses, bishops command the dioceses, and priests with jurisdiction in their parishes (ROSENDAHL, 2012).

Now, not only religious territories controlled by a religious professional in its three hierarchical levels, such as the Vatican, Dioceses and Parishes (ROSENDAHL, 2012), become necessary for institutional continuity, as we have in descending scale of political-administrative 
hierarchical importance in the Catholic Church, it is also necessary to expand its territorial boundaries to other territories such as cyberspace and the media.

Territories from cyberspace - websites, blogs, Facebook, games, smartphone applications, YouTube and media channels - catholic television networks and the radio are vital to ensure the continuity of the Church. From the Second Vatican Council onwards, the emergence of the Catholic Charismatic Renewal (CCR) movement is giving rise to a religious revival. In addition, it is a movement that focuses on reaching young people ${ }^{3}$ and promote a renewal and provided the creation of new strategies for spreading the Catholic faith, thus reducing the loss of the faithful (OLIVEIRA, 2014, 2015, 2017).

In a postmodern context, especially from the hypermodernity, with its context of diffusion of faith through the media and the market, Silveira $(2014$, p.221) points out:

Uncoupled from its original locus and circulating through the consumption of symbolic-material goods, the imagistic representations are catapulted by the mass and electronic media, in a process of convergence with new physical platforms (cell phones, iPads, iPhones), potentializing the circuit of consumption and strongly affecting the way the religious is conceived, the experience of the sacred and religions.

According to Emerson Silveira (2014, p. 221), "it is in hypermodernity, understood as an acceleration of capitalist modernity in its dynamics and internal contradictions, that religion interacts with consumption and spectacle, torn between autonomy and heteronomy, hardening and liquefaction, repetitions and inventions". This statement demonstrates the liquidity of the religious phenomenon in the current period in which society is inserted.

From hypermodernity, the development of technologies and new ways of seeing and feeling the sacred, the catholic territoriality has reached new heights from the diffusion through the media, including television, radio, and internet. The parish used to be the main place for contact and experience of the Catholic faith, but then it began to give place to experiences outside their physical borders, which has resulted in an expansion of its territoriality.

The highlight of these transformations occurs through the media - radio programs, such as that of Priest Marcelo Rossi, allow the devotee to transcend into a 'sacred space imaginalis' space of encounter with the sacred (ROSENDAHL, 2002).

\footnotetext{
${ }^{3}$ The relationship between Catholic youth and the Catholic Charismatic Renewal can be analyzed from the book Religion and Youth: the new charismatics by the sociologist Flávio Sofiati (2011), which addresses the theme of youth and its relation to the movement of RCC, as well as the new socio-cultural transformations in the contemporary society that impresses a new characteristic and action of the Catholic youth that they experience their religious practice differentiated from the secular youth, I other words, non-religious.
} 
Therefore, we can categorize the diffusion of the Catholic faith in the hypermodern period from two perspectives: a) diffusion through the media - television, radio and internet and; b) diffusion through the market perspective, following the media-consumerist logic - concerts, musical events, priests and writers, books aimed at the religious market, religious bands of pop, rock, poprock, among other actions.

The focus in $A$ is on the study of the media and its diffusion process. How does religion appropriate these means to propagate/diffuse its doctrine? In $\mathrm{B}$, the focus is on the perspective of the consumption and production of religious symbolic goods, as well as the market view of major events, concerts etc. Although our emphasis is on Catholicism - CCR, the same analysis can be carried out for other religious doctrines that are embedded in the context of the online diffusion of faith.

The communicologist and journalist Moises Sbardelotto makes usage of the word 'bit' in his book "E o verbo se fez bit: a comunicação e a experiência religiosa na internet" - And the verb became bit: the communication and the religious experience on the internet (2012), which in Computer Sciences means binary digit, being the smallest unit of information which can be stored or transmitted to portray the new relations between the religious individual and the sacred in the postmodern period. If before the physical and concrete verb was the word of God, in the present day a new verb arose, in other words, God is available on the web, enabling the religious individual to have access to different interactions with the sacred in a religious and digital environment.

Today, through digital media - especially the internet - the configuration of a 'new verb', of a new type of faithful-sacred relationship is manifested. In a 'generalized communication society', especially from the emergence of digital media, we perceive that the internet also becomes an environment for religious practices, which characterizes a phenomenon of the mediatization of contemporary societies (SBARDELOTTO, 2012: 23).

The media in the hypermodern context has a vital importance of intelligibility in order to comprehend the new social relations. As pointed out by Joana Puntel $(2012$, p.63), the media "is a complex system that no longer simply involves the media, but the subject, the media (artifacts), media organizations with their various combinations and articulations: advertising, marketing". Thus, the author continues to relate media as a complex system, where "it is in it that the contemporary individual moves, articulates, feeds, produces, consumes and satisfies his/her desires, through the variety and diversity of possibilities always in increasing innovation". A dialogue with Roger Silverstone (2002, p.9) can be made, when he stresses that we cannot escape the media, it is present in every aspect of our daily lives. 
Brazil is also internationally recognized, not only for its natural and cultural beauties but also for what is produced and disseminated abroad through the media, especially soap operas. In the meantime, the interest of Brazilians in the media is noticeable and in the last decade, in particular, it was shown growth in the usage of internet and social media. For the religions present in Brazil, entering cyberspace and media power enable substantial growth and the diffusion of ideas.

In 2017, Wearesocial ranked, from all the countries of the world interconnected in the social media, considering internet connection time per day, Brazilians appear in second place with an average daily access of 3 hours and 43 minutes. They lose only to the Philippines with 4 hours and 17 minutes and being ahead of developed countries with recognized active participation on the Internet, like the United States, Japan, China and some European countries. On a global scale, these data reveal an important information about how cyberspace is something to be explored, not only in the commercial and economic sense, but also in social, cultural, and academic studies.

Geographically analyzing this data and information, cyberspace now becomes one of the main tools of diffusion of economic, political and social information, on a worldwide scale. Also, according to Wearesocial, Brazil appears not only in second place in connection hours per day but also presents more than $90 \%$ daily connection on the internet. With a population estimated at more than 207 million people (IBGE, 2017); more than half of this total has access to the internet, meaning more than 100 million users.

The love of Brazilians for social networks has begun in 2004 when one of the first social networks became a fever in Brazil, the Orkut, created by the Turkish engineer Orkut Büyükkökten, who worked at Google. Orkut became a success almost immediately, bringing together people who looked for social relationships, making new friends, meeting old friends online and engaging themselves in numerous communities with cultural, political, economic, social, technological contents. Previously, the use of chat-programs, such as MSN Messenger, ICQ, as well as Yahoo, $A O L, I G, U O L$ chats, were the main instruments for social activities and experiences in the online universe.

However, being inserted in a globalized world, ruled by a world culture, means that each day, not only the technology of smartphones evolves in a daily basis, always seeking new consumers, but also networks and social media are constantly changing and adapting themselves to the new reality of the internet user. If we were previously based on a Web 1.0, where the interaction between user vs. computer and the internet was almost nonexistent, Web 2.0 has come 
to break new paradigms and bring interaction to the users - networks, social media, YouTube and other accessibility tools.

Going back to the Orkut case, which was especially beloved in Brazil, it was losing visibility due to the rise of another global social network since 2014 named Facebook. Today, the social network created by the American Mark Zuckerberg and friends has a little more than two billion accounts (STATISTA, 2017) and, in Brazil alone, Facebook counts more than 100 million profiles (WEARESOCIAL, 2016).

It is remarkable that more than $80 \%$ of the Brazilian population is active on the internet and has an account in the social network. In addition to Facebook, other social networks and applications stand out, like WhatsApp - messaging, audio and video application with over 1.2 billion users; YouTube - a network of videos with more than 1.5 billion users; Instagram - a social network of photos with more than 700 million users (STATISTA, 2017). All these data confirm the importance of cyberspace in the analysis of religion and its virtual practice.

These virtual spaces inserted in cyberspace are a field of struggle in the case of Brazilian Christian churches and other religious doctrines in search of their virtual territory. Having such a profile/fan page on Facebook, a channel on YouTube, a social profile on Instagram or Twitter is now a fundamental tool for spreading religious content and the word of God. The virtual territories are mostly managed by the institutions themselves, which carry out a process of virtual territoriality in these virtual spaces and/or places that are protected, diffused and shared by their devotees.

Pope John Paul II, during the 36th World Day of Social Communications in 2002, stressed the importance of the internet for the Church, once, according to him, the internet constitutes a new forum and a new front of evangelization. He also pointed out that internet could be used both in beneficial aspects and in the act of exposing the worst aspects of human nature. For him, the "(...) cyberspace is, so to speak, a new frontier that opens at the beginning of this new millennium' and still continues to emphasize that for the Church, 'the new world of cyberspace is an exhortation to the great adventure of using their potential to proclaim the Gospel message." (Pope John Paul II, 2002).

Considered by many to be a more academic Pope, Pope Emeritus Benedict XVI, during the 47th World Communications Day, held in 2013, also highlighted the importance of the digital environment and social networks as tools that give people an opportunity for prayer, meditation or sharing the word of God. Also, according to Pope Benedict XVI, the networks offer openness to other dimensions of faith from the online experience in relation to relationships between the community and even pilgrimages. Therefore, "by looking forward to making the Gospel present in 
the digital environment, we can invite people to have prayer meetings or liturgical celebrations in concrete places such as churches or chapels" (POPE BENEDICT XVI, 2013). He ends his speech by stressing that there should be no lack of coherence or unity between the expression and testimony of faith in either physical or digital living.

Following the same strategy of Pope John Paul II and Benedict XVI, the current Pope Francis, during a Plenary Session of the Pontifical Council for Social Communications (PCSC) in 2013 , has stressed out that it is important for the Church's presence in the world of communication "to dialogue with the people of today and lead them to meet Christ, in the certainty, however, that we are means and that the fundamental problem is not the acquisition of sophisticated technologies, although necessary for a current and valid presence" (CANÇÃO NOVA NOTÍCIAS, 2013).

\section{Final considerations}

From hypermodernity, the advancement of technologies and new ways of seeing and feeling the sacred, the catholic territoriality has reached new heights from its diffusion through media, including television, radio, and internet. Before the parish as the main place of contact and experience of the Catholic faith, it began to give place to experiences outside its physical borders, that is, an expansion of its religious territoriality occurred.

The spread of the online faith and the different kinds of the spread of religion in the message flow in the media allow us to reach countless devotees. It represents an information flow from the religious message through different means of different uses of information technology. We consider that religious individual in hypermodernity not only has his/her traditional characteristics and practices of seeing and feeling the sacred (GRECO, 2009; ROSENDAHL, 2003) but also presents new practices of experiencing the faith from the media and cyberspace, which consists of a virtual religious practice, imaginary and symbolic.

The media nowadays enables such relations and exchanges. It holds a great power of influence on providing a catalysis that leads to changes in the society. Religion attempts to follow this process by creating strategies to assure its devotees in face of such changes. This dialectical relationship brings also positive and negative points in a growing duality. The first might make the religious individual more alive and engaged in his/her religious practices at media and cyberspace through different strategies created by the religions in their different temporalities and spatialities. 
The latter leads to a consequent distance of the religious individual from his/her religious practices and his/her faith, caused by the pursuit of individuality and the excessive use of technology.

\section{References}

ADAM, Barbara. Time. Cambridge: Polity Press, 2004.

ALMEIDA, Maria Geralda de e RATTS, Alecsandro J.P. Geografia: Leituras Culturais. Goiânia: Editora Alternativa, 2003.

BAUMAN, Zygmunt. Comunidade: a busca por segurança no mundo atual. Tradução Plínio Dentzien. Rio de Janeiro: Jorge Zahar Ed, 2003.

BAUMAN, Zygmunt. Modernidade Líquida. Tradução: Plínio Dentzien. Rio de Janeiro: Zahar, 2007.

BAUMAN, Zygmunt. Vida para consumo. A transformação das pessoas em mercadorias. 3ed. Trad. Plínio Dentzien. Rio de Janeiro: Zahar, 2008.

BERGER, Peter Ludwig. O Dossel Sagrado: Elementos para uma Teoria Sociológica da Religião. São Paulo: Paulus, 1985.

BERGER, Peter Ludwig. A dessecularização do Mundo: uma visão global. In: Religião e Sociedade, Rio de Janeiro, 21(1): 9-24, 2000.

CANÇÃO NOVA NOTÍCIAS. Site with a online newspaper about religion, 2013. Available at:<https://noticias.cancaonova.com/especiais/pontificado/

francisco/cristaos-devem-ser-presenca-nos-meios-de-comunicacao-diz-papa/>.

CARRANZA, Brenda e MARIZ, Cecília Loreto. Novas comunidades católicas: por que crescem? In: CARRANZA, Brenda; MARIZ, Cecília e CAMURÇA, Marcelo. (Org.) Novas comunidades católicas: em busca do espaço pós-moderno. Aparecida, SP: Ideias \& Letras, p. 139-170, 2009.

CASTELLS, Manuel. A sociedade em rede. São Paulo: Paz e Terra, 1999.

CLAVAL, Paul. A Geografia Cultural. Florianópolis: Editora da UFSC, 1999ª.

CLAVAL, Paul. Reflexões sobre a Geografia Cultural no Brasil. Espaço e Cultura (UERJ), n. 8, p. 7-29, $1999 \mathrm{~b}$.

CLAVAL, Paul. A geografia cultural no Brasil. In: BARTHE-DELOIZY, F., and SERPA, A., orgs. Visões do Brasil: estudos culturais em Geografia [online]. Salvador: EDUFBA; Edições L'Harmattan, pp. 11-25, 2012.

CORREAA, Roberto. L. Espaço e Tempo: Um Tributo a Mauricio Abreu. Revista Cidades, São Paulo, v. 8, n. 14, 2011. 
CORREAA, Roberto. L e ROSENDAHL, Zeny. Introdução à Geografia Cultural. Rio de Janeiro: Bertrand Brasil, 2003.

COSGROVE, Denis. A geografia está em toda parte: cultura e simbolismo nas paisagens humanas. In: ROSENDAHL, Zeny; CORRÊA, Roberto Lobato (Org.). Paisagem, tempo e cultura. Rio de Janeiro: EDUERJ, p. 92-122, 1998.

ELIADE, Mircea. O Sagrado e o Profano. A Essência das Religiões. Tradução por Rogério Fernandes. Lisboa, Edições Livros do Brasil, 1962.

GOMES, Paulo C. C. Cenários para a Geografia: sobre a espacialidade das imagens e suas significações. In: CORREAA, R. L e ROSENDAHL, Z. (Org). Espaço e Cultura: Pluralidade Temática. Rio de Janeiro: EdUERJ. pp. 187-209, 2008.

GRECO, Carlo. A experiência religiosa - essência, valor, verdade. São Paulo: Loyola, 2009.

IBGE. INSTITUTO BRASILEIRO DE GEOGRAFIA E ESTATÍSTICA, 2010.

IBGE. INSTITUTO BRASILEIRO DE GEOGRAFIA E ESTATÍSTICA, 2015.

IBGE. INSTITUTO BRASILEIRO DE GEOGRAFIA E ESTATÍSTICA, 2017.

KONG, Lily. Geography and Religion: trends and prospects. In: Progress in Human Geography. Vol. 14, No. 3, 355-71, 1990. Disponível em: <http://profile.nus.edu.sg/fass/geokongl/ping14.pdf> AcessAccessed on January 15, 2019.

LÉVY, Pierre. O que é virtual? São Paulo: Editora 34, 1996.

LÉVY, Pierre. Cibercultura. Tradução de Carlos Irineu da Costa. São Paulo: Editora. 34, 1999.

LIPOVETSKY, Gilles e CHARLES, Sébastien. Os tempos hipermodernos. São Paulo: Barcarolla, 2004.

LIPOVETSKY, Gilles e SERROY, J. A cultura mundo, resposta a uma sociedade desorientada. Tradução: Maria Lúcia Machado. São Paulo: Companhia das Letras, 2011.

LIPOVETSKY. Gilles e SERROY, J. A estetização do mundo: viver na era do capitalismo artista. São Paulo: Companhia das Letras, 2015.

MIKLOS, Jorge. Ciber-religião: a construção de vínculos religiosos na cibercultura. Aparecida, SP: Ideias \& Letras, 2012.

NORTON, William. Cultural geography: themes, concepts, analyses. Oxford University Press, 2000.

OLIVEIRA, Jefferson R. de. (2011). Representações e práticas religiosas da Renovação Carismática Católica em Cachoeira Paulista: o exemplo da Canção Nova. Espaço e Cultura (UERJ), v. 30 , p. 36-54, 2011. Available at: <http://www.epublicacoes.uerj.br/index.php/espacoecultura/article/view/4951>. 
OLIVEIRA, Jefferson R. de. A Igreja Católica e a difusão da fé na hipermodernidade: o exemplo do mass media e as online communities. Espaço e Cultura (UERJ), v. 36, p. 89-115, 2014. Available at:

http://www.epublicacoes.uerj.br/index.php/espacoecultura/article/view/18907/13704

OLIVEIRA, Jefferson R. de. Canção Nova e as Peregrinações Pós-Modernas: Hierópolis Carismática de Cachoeira Paulista - SP. São Paulo: Paco Editorial, 2015.

OLIVEIRA, Jefferson R. de. $O$ on e 0 off da fé na hipermodernidade: a religião e as novas interfaces do sagrado na era 2.0. O exemplo no Vale do Paraíba (SP). 2017. 267 f. Tese (Doutorado em Geografia) - Instituto de Geografia, Universidade do Estado do Rio de Janeiro, Rio de Janeiro. Available at:

http://www.bdtd.uerj.br/tde_busca/processaPesquisa.php?pesqExecutada=1\&id=10199>.

OLIVEIRA, Jefferson R de; ROSENDAHI, Zeny. Religião, Política e Espaço: a difusão da fé através do Mass Media e as Online Communities. In: MOREIRA, Alberto da [et al.]. Religião, espetáculo e intimidade: múltiplos olhares. Goiânia: Ed. da PUC Goiás, 2014.

PAPA BENTO XVI. $47^{\circ}$ World Communications Day. Available at: $<$ http://w2.vatican.va/content/benedict-xvi/pt/messages/communications/documents/hf_benxvi_mes_20130124_47th-world-communications-day.html>, 2013. Accessed on January 15, 2019.

PAPA JOÃO PAULO II. $36^{\circ}$ World Communications Day. Available at: $<$ https://w2.vatican.va/content/john-paul-ii/pt/messages/communications/documents/hf_jpii_mes_20020122_world-communications-day.html>, 2002. Accessed on January 15, 2019.

PARK, Chris. Sacred Worlds: an introduction to geography and religion. Routledge, London, 1994.

PARK, Chris. Religion and geography. In: Hinnells, J. (ed.) Routledge Companion to the Study of Religion. London: Routledge, p.1-29, 2004.

PUNTEL, Joana T. Mídia e construção do desejo. In: VILHENA, Maria Angela; PASSOS, João Décio (orgs.). Religião e consumo: relações e discernimentos. São Paulo: Paulinas, 2012.

ROSA, Hartmut. Alienation as Acceleration. Towards a Critical Theory of Late-Modern Temporality, NSU Press, 2010.

ROSENDAHL, Zeny. Espaço, Política e Religião. In: ROSENDAHL, Z. e CORREAA, R. L (org.), Religião, Identidade e Território, Rio de Janeiro: EdUERJ, 2001.

ROSENDAHL, Zeny. Espaço e Religião: uma abordagem geográfica. $2^{\circ}$ ed. Rio de Janeiro: EdUERJ, 2002.

ROSENDAHL, Zeny. Espaço, Cultura e Religião: Dimensões de Análise. In: ROSENDAHL, Z;; CORREA, R. L (orgs.). Introdução à Geografia Cultural. Rio de Janeiro: Bertrand Brasil, 2003.

ROSENDAHL, Zeny. Hierópolis e Procissões: o sagrado e o espaço. In: Religião \& Cultura: Espaço Sagrado e Religiosidade. PUC/SP. n`14 (julho./dez. 2008). São Paulo: Paulinas-Educ, 2008. 
ROSENDAHL, Zeny. Primeiro a Obrigação, Depois a Devoção: estratégias da Igreja Católica no Brasil, de 1500 a 2005. Rio de Janeiro: EdUERJ, 2012.

SACK, R. D. Human territoriality: its theory and history. Cambridge: Cambridge University Press, 1986.

SBARDELOTTO, Moisés. "E o verbo se fez bit": a comunicação e a experiência religiosa na Internet. Aparecida, SP: Editora Santuário, 2012.

SILVEIRA, Emerson Sena da. Espetáculo, Religião e Consumo: passagens e tensões na hipermodernidade. In: MOREIRA, Alberto da [et al.]. A Religião entre o espetáculo e intimidade. Goiânia: Ed. da PUC Goiás, 2014.

SILVERSTONE, Roger. Por que estudar a mídia? São Paulo: Loyola, 2002.

SKORKA, A; BERGOGLIO, J. Sobre o céu e a Terra. Tradução: Sandra Martha Dolinsky. São Paulo: Paralela, 2013.

SOPHER, David. Geography of Religions. Prentice-Hall, New York, 1967.

STATISTA. Site of statistics of networks and social media. Available at: <https://www.statista.com/statistics/272014/global-social-networks-ranked-by-number-of-users/>, 2017. Accessed on January 15, 2019.

STUMP, Roger W. The geography of religion: faith, place, and space. Lanham, Rowman \& Littlefield Publishers, 2008.

WEARESOCIAL. Website with information about social media and internet. Available at: < https://wearesocial.com/uk/special-reports/digital-in-2016>, 2016. Accessed on January 15, 2019.

WEARESOCIAL. Website with information about social media and internet. Available at: $<$ https://wearesocial.com/special-reports/digital-in-2017-global-overview>, 2017. Accessed on January 15, 2019. 